\title{
GCU
}

Glasgow Caledonian

University

University for the Common Good

\section{Affective equality: love matters}

Cantillon, Sara; Lynch, Kathleen

Published in:

Hypatia

DOI:

10.1111/hypa.12305

Publication date:

2017

Document Version

Author accepted manuscript

Link to publication in ResearchOnline

Citation for published version (Harvard):

Cantillon, S \& Lynch, K 2017, 'Affective equality: love matters', Hypatia, vol. 32, no. 1, pp. 169-186.

https://doi.org/10.1111/hypa.12305

\section{General rights}

Copyright and moral rights for the publications made accessible in the public portal are retained by the authors and/or other copyright owners and it is a condition of accessing publications that users recognise and abide by the legal requirements associated with these rights.

Take down policy

If you believe that this document breaches copyright please view our takedown policy at https://edshare.gcu.ac.uk/id/eprint/5179 for details of how to contact us. 


\section{Affective Equality: Love Matters}

And did you get what

you wanted from this life, even so?

I did.

And what did you want?

To call myself beloved, to feel myself

beloved on the earth $<1>$

\section{Affective Equality, Nurturing and Social Justice}

The nurturing that produces love, care and solidarity constitutes a discrete social system of affective relations. Affective relations are not social derivatives, subordinate to economic, political or cultural relations in matters of social justice. Rather, they are productive human relations that literally make people up (or damage them) mentally, emotionally, physically and socially. The affective worlds of love, care and solidarity are therefore sites of political import for social justice that need to be examined in their own right while recognizing their interrelatedness with economic, political and cultural systems (Baker, Lynch, Cantillon and Walsh 2004). 
Building on the work of care feminists, and especially Fraser's more recent work on parity of participation and social justice, we argue that to enable people to have the 'participatory parity' that Fraser regards as a core principle guiding global justice, we need to move beyond the equalization of resources, respect, and representation--what Fraser calls the three 'conditions' of social justice (Fraser 2010: 365). Because the affective domain is a discrete site for generating inequality in the relational sphere, both independently of, and intersectionally with, economic, political, and cultural relations, we argue that to promote love we need a fourdimensional model of social justice (Lynch 2014). That is, a model that aligns relational equality with equality of resources, respect and representation is required. We believe that this would entail deconstructing and reconstructing both gender and capitalist relations. This article states the case for the salience of love as a social justice issue by demonstrating the importance of securing equality in the nurturing of one another, not only in the intimate spheres of life but also in our secondary care and solidarity relationships, which is required in part because of the iterative relationship between the different spheres of nurturing. We also recognise the importance of securing equality in the doing of the emotional, physical and mental work involved in creating love, care and solidarity relations.

One of our main arguments is that love matters because it is what produces us in our relational humanity; it is the primary element of our 'humane co-affective relations' through which we make and remake each other (Matheis 2014, 12). Love both enhances the capacity of our lives and enables our moral transformation (hooks 2000). People, individually and collectively, cannot participate fully as relational beings in families, professional, political or other areas of 
life without the experience of being nurtured. As the affective relations involved in reproducing love, care and solidarity is a core part of what produces them as human beings (Oksala $2016,297)$, to be deprived of love (primary care), and also of secondary and tertiary care, which facilitate and enable love, is a major social injustice.

A further claim we make in the paper is that love matters because the labor involved in producing love -love labor $<2>-$ is both inalienable and non-commodifiable. The emotional work involved in loving a given person cannot be assigned to another by a commercial or even a voluntary arrangement without undermining the premise of mutuality that is at the heart of intimacy (Strazdins and Broom 2004; Lynch 2007). For example, one cannot pay someone to go for a meal with a friend or a partner without fundamentally changing the nature of the event. Because a core part of love relationships (whether lovers, friends or family) is the maintenance of the bond of intimacy, being in the presence of, and with, the other in time and space is a vital element in promoting love. To attempt to substitute, or commodify, the intimate part of the love relationship would change it into something else. We believe that what distinguishes love most from other forms of caring is its non-substitutionability.

To say that love is distinct from other forms of caring is not to deny that in the practice of loving, desiring and caring, the boundaries between forms of love and care cannot be neatly drawn. The all too human self-intervenes. As Traustadottir (2000) observes, while we can make a distinction between emotions and activities, they are not so easily separated in practice. Professional (theoretically, non-love) care relationships can and do transform into friendships in specific contexts. Relations that appear to be governed by a one-sided kind of 
love (where there is unfailing love over time for a parent or a very ill child) do call forth some form of reciprocation, even if only in the form of a smile; and they involve relations of power and control as well as love (Lynch, Lyons and Cantillon 2009a).

In understanding love, it is also necessary to distinguish between affective relations of love, care and solidarity as a system of caring relations, and the emotionally-driven commercial care work undertaken in a market context (Hochschild 1979). Affective care relations are also analytically distinguishable from affective actions operating in the exercise of political power (Ahmed 2004; Lakoff 2008).

Like Ferguson (2014) we regard loving, and the affective relations in which it is embedded, as highly materialized. The labor that produces love is undertaken through affection, commitment, attentiveness, and the material investment of time, energy, and resources. It involves, at different times and in various forms, friendship, desire, and/or other-centeredness where there may be little or no reciprocation, or seeming merit or deservedness, for receiving love.

Moreover, love laboring is very unequally distributed between women and men, with the result that women's exploitation as love laborers is arguably the principal form of exploitation that applies specifically to them as women (Bubeck 1998; Lynch, Baker and Lyons 2009). Thus love also matters because of the salience of the affective system as a discrete site for generating gender and, increasingly, racially-related injustices (Gutierrez-Rodriguez 2014). To create socially just and gender just societies, public policies need to be directed by norms of love, care and solidarity rather than norms of capital accumulation. 


\section{The Neglect and Recovery of Love}

Feminist scholars have taken issues of care and love out of the privatised world of the family to which they had been consigned by most political and legal theorists (Gilligan 1982, 1995; Tronto 1987, 1993; Okin 1989; Ruddick 1990; Benhabib 1992; Kittay 1999; Sevenhuijsen 1998; Fineman 2004; Held 2006). They have drawn attention to the salience of care and love as public goods, and have identified the importance of caring as a human capability meeting a basic human need (Nussbaum 1995; hooks 2000). Feminist scholars have also played a key role in exposing the complex ways in which exploitative gendered power relations are embedded in love and care relations (Ferguson 1989; Delphy and Leonard 1992; Folbre 1994; Jónasdóttir 1994; Bubeck 1995; Fraser 1997). In making love and care public and problematic, feminists have highlighted the affective domains of life as discrete sites of social action, sites that are deeply interwoven with the economic, political and cultural spheres.

Despite the advances of feminist thinking on care and justice, however, much of their scholarship is ignored or peripheralized in discussions on social justice in political theory. In contemporary theory, including feminist theory, focusing on the subject of love 'in particular evokes embarrassed responses, similar to what the formerly taboo topic of sex used to elicit' (Toye 2010, 40). While there are exceptional political theorists, such as Axel Honneth (2003, 143) who regard love as 'the central idea of intimate relationships' and a form of 'affective recognition' central to the realisation of equality, most branches of the social and political science neglect love relations, concentrating instead on the political relations of the state, the economic relations of the market, and the cultural relations governing social recognition $<3>$. 
Love and care tend to be analyzed either as problems of the good life such as in the work of Habermas (1981) or, as Okin (1989) and Tronto (1987) observed almost thirty years ago, not sufficiently important to be addressed in mainstream theories of justice and politics.

Contractual models of social relations tend to inform dominant moral theories and 'are built on liberal models of social relations between strangers' (Held 2006, 80) with the result that the love life of the affective world is often ignored. Rational choice theorists are even stronger in their allegiance to contractualism regarding all social relations 'as between independent, autonomous, self-interested individuals' (ibid). This separatist view of personhood largely ignores the reality of human dependency and interdependency across the life course (Benhabib 1992; Kittay 1999). The idealization of autonomy, choice and self-interest as the over-riding orientations of social relations has placed a premium on the analysis of a human condition that is never fully realizable (England 2005).

\section{Affective Relations and Participatory Parity}

In her ground-breaking essay on reimaging the welfare state, Fraser argued for the development of a Universal Care-giver model as a utopian ideal for overcoming the many gendered injustices underpinning both universal breadwinner and care-giver parity models of welfare. Fraser argues 'the key to achieving gender equity in a postindustrial welfare state is to make women's current life -patterns the norm for everyone'. Specifically, she states the Universal Care-giver model would require that: 
'...all jobs would be designed for workers who are caregivers, too; all would have a shorter workweek than full-time jobs have now; and all would have the support of employment-enabling services. Unlike Universal Breadwinner, however, employees would not be assumed to shift all carework to social services.' (Fraser 1997, 61)

Given the high priority that Fraser attributed to equalizing caring as a fundamental requirement for gender justice, it is surprising that the care and love domains of life are not incorporated into her framework for realizing global justice in her more recent work $(2005,2008$, 2010). Arguing that equality and social justice are principally problems of parity of participation, Fraser claims that the key issue for promoting justice is that it permits all members of the global community to interact with one another as peers. To achieve participatory parity she outlines three key conditions: equality in economic, political and cultural relations through the equalization of material resources; equalizing respect for different status groups and, finally, constituting society politically 'to accord roughly equal political voice to all social actors'. (Fraser 2010, 365). Equalizing relations of love and care is not named as a key condition for social justice.

While Fraser's work is a sophisticated theoretical framework for mapping solutions to the issues of social justice globally, not least in highlighting how ' the state-territorial frame is imposed on transnational sources of injustice (Fraser 2008, 114), the new 'frame' does not analyze the affective domain of life as a discrete site of social practice. By not doing so, we believe it seriously neglects love and care relations as sites for the generation of social injustices, injustices that are especially experienced by women. As Kittay (1999) and other feminists 
(Folbre 1994; Gilligan 1995; hooks 2000; Fineman 2004) have observed, the issue is not to choose between equality and care but to develop a 'connection-based' conception of equality and justice that recognizes that dependency is a typical condition of human life, that dependents need care, and that dependency workers, both paid and unpaid, cannot and will not have parity of participation in social or political life without recognizing the primacy of affective relations in the framing, and mis-framing, of social justice. The remainder of the paper outlines why affective relations, and especially love, matter for social justice.

\section{Affective Relations and Love}

Studies of infants show that 'the desire for relationship, pleasure in connection and the ability to make and maintain relationship are present at the onset of development' (Gilligan 1995, 123), while a 'neurobiology of attachment' is emerging that is helping to illuminate the importance of love (Damasio 2006). Nurturing love is what produces people in their relational humanity as mentally healthy, warm and considerate human beings. Love secures our sense of self emotionally and gives us the capacity to show our vulnerability as well as the ability to show our strength (Nussbaum 2013). Within the sphere of affective relations, love relations are located at the heart of three major overlapping systems of nurturing, each of which is distinguishable from the other (Figure 1) 
Figure 1 Concentric Circles of Affective Care Relations*

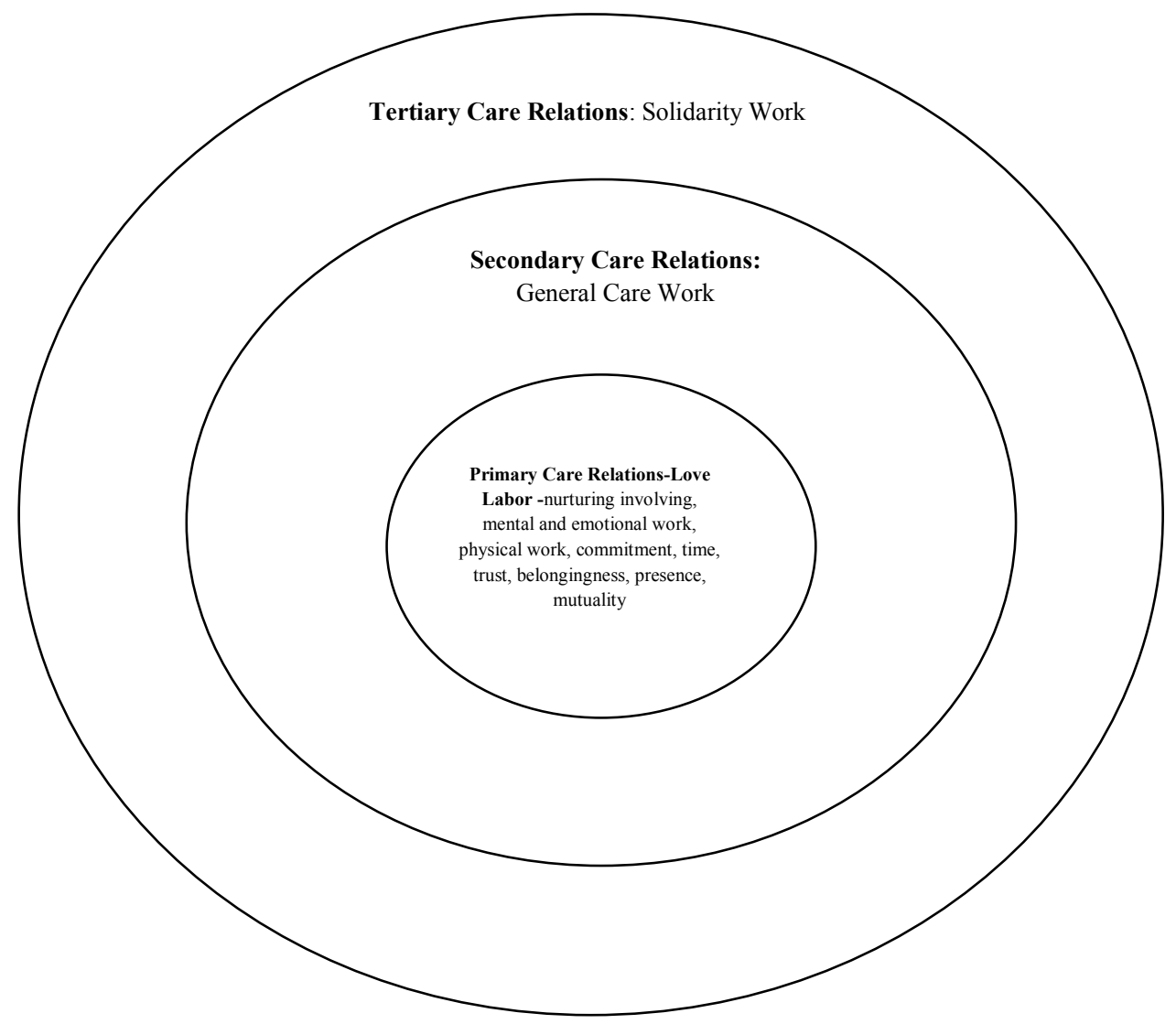

*adapted from Lynch (2007) 
Love is first produced in the primary world of intimate relations where there is strong attachment, interdependence, deep engagement and intensity $<4>$. It is produced through love laboring and the prototypical relationship in this circle is that between parents and children $<5>$. Even in situations where there is minimal love labor invested by the parties to this intimate world, or where there is abuse or neglect, these relationships still retain a high level of emotional and relational significance.

The care work involved in maintaining affective bonds with neighbours, community associates, and/or work colleagues, or the caring given in teaching or nursing or paid caring, operate in the secondary space of affective relations. However, while the socio-spatial site of primary care relations may be within kinship networks and families (and is generally for young children and among partners) it need not always be, depending on the depth of intimacy and friendships developed over time in neighborhoods, community associations, work contexts or other social networks: colleagues at work or in communities of action or association can and do become intimate others, and the focus of love relations. Also, to highlight the primacy of intimate love relations is not to deny the way love labor and secondary care work can and do become closely intertwined, with love sometimes emanating from the activity of care (Traustadottir 2000; Folbre 2012; Tronto 2013).

Tertiary affective relations involve solidarity work, where people have responsibilities through democratically constituted statutory obligations $\langle 6\rangle$, or where people work informally, politically, culturally or economically through solidarity to challenge injustices. While solidarity varies in form and context, and has many different manifestations, from the more limited form 
of voting to maintain the redistribution provisions of the welfare state, to a more major commitment such as political solidarity with minorities, or to collective action 'in response to a situation of injustice or oppression' with the intention of challenging injustice (Scholz 2007, 43), it is a form of collective caring and politicized loving of others that is vital in the global struggle against neoliberal capitalism at the transnational level (Mohanty 2003; Ferguson 2014).

\section{Distinguishing Care and Love Labor}

One of the principal factors that distinguishes love relations from other care relations is that their principal goal is the enhancement of the love relationship itself. Nurturing others is a primary focus of love relations; it is an other-centered feeling and way of regarding and attending to another while relating. The love labor that produces love through nurture variously involves physical, cognitive and mental work as well as emotional work (Ruddick 1990). It is in everyday undertakings that it is created, doing practical physical tasks such as cooking favorite meals for a friend, a child or partner, listening to cares and worries, massaging the body, or giving financial help if needed. At the mental level, it involves holding the persons and their interests in mind, keeping them "present" in mental planning, and anticipating and prioritizing

their needs and interests. Emotionally, it involves affirming, supporting and challenging, as well as identifying with someone and supporting them emotionally at times of distress (Mattingly 2014). Love involves the very real activities of "looking out for", and "looking after" the other, including the management of the tensions and conflict that are an integral part of love labor relations (McKie et al. 2002). While a child care worker, a nurse or a teacher will have to care for those for whom they have a care duty, the primary purpose of the relationship is not to 
develop an intimate mutually supporting love-led relationship. The teacher educates, the nurse restores people to good health, the child care worker protects and enhances children's development and general well being; their goals are realized through caring; they may, and often do, come to love a person for whom they care, but loving is not in itself the relationship's primary purpose.

The labor that is involved in producing love in primary care relations is also distinct from the emotional social, and/or physical work involved in creating and maintaining secondary care relations because the affective engagement in terms of time, responsibility, commitment and emotional engagement is more intense and prolonged (Engster 2005). Neither the moral imperative to do other-centered work, nor the expectations of trust, mutuality, and attentiveness that are part of love laboring are present to the same degree in secondary care relations. Love labor does vary however, in the level of intensity and degree of commitment depending on the context and cultural and legal norms. For example, the moral and legal imperatives to care for and love dependent children is much stronger than is the imperative to care for and love ageing parents in most Western cultures; and love for friends is more loosely defined as a lesser expected commitment, as indeed is care for sisters or brothers, especially in Western societies.

Love relations also have a different time trajectory than other care relations. While love relations are like hands-on caring in that neither can be dictated by bureaucratic time, since they are based on human needs and arise from certain vulnerabilities and dependencies, neither care nor love are ordered on clock time (Bryson, 2013). However, unlike paid care time, 
love laboring time is person-specific, and it also has a longer and more unpredictable trajectory as it is not tied to a time-bound contract.

While hands-on caring of necessity requires physical presence, love involves physical presence to a more intense degree, as spatial distances make it more difficult to relate intimately. The attentiveness to bodily presence and affection that are possible in the physical presence of another cannot be given, or at least in the same way, at spatial distances.

Love laboring is not entirely altruistic; the bonds that develop in love relationships have the potential to be mutually beneficial. There is a sense of mutual dependence no matter how challenging the relationship may be. Furthermore, the loved recipient is not necessarily a silent or powerless partner, a tabula rasa for someone else's love labor (Lynch, Lyons and Cantillon 2009a). Those who are more dependent can show appreciation for love or fail to show it. When the love-giver is a woman, the love recipient can call on the gendered moral imperatives on women to be caring in order to enforce their love and care expectations and in that way exercise care commands on carers (Bubeck 1995).

Love and care laboring also differ in terms of emotional intensity. While providing intimate care for others can and does involve emotional work, the relationship is generally one that is emotionally bounded (be it child care, elder care, teaching or nursing care). This is not true for love laboring work. The love laboring required to nurture primary care relations involve a range of emotionally-laden responsibilities, including holding the person in mind, planning, listening, attending and making commitment to the relationship itself, that do not apply to other care relations. 
What we are suggesting, therefore, is that the realization of intimate love, as opposed to the declaration of love, requires work. Without such laboring, feelings of love or care for others can simply involve rhetorical functionings, that is, words and talk that are declaratory in nature but lack substance in practice or action. Verbal utterances of affection, care or solidarity (which may be valuable in themselves) become empty and formulaic when they are not complemented by undertakings on behalf of others. Love labor, and paid and unpaid care labor have immaterial dimensions but they are also highly materialized and "exemplary of an embodied practice" that "is deeply relational" (Lanoix 2013, 86).

\section{Inalienability of Love}

One of the factors that distinguishes love most of all from secondary caring and solidarity is its inalienability and non-commodifiability. While many secondary care tasks are commodifiable, and there is a case for substantially improving the conditions of paid care and domestic labor to preclude care-related exploitation (Meagher 2002), love labor cannot be commodified because it is non-substitutable.

The love labor that produces a sense of support, solidarity and well-being in others is voluntarily given; it is relationally specific, and chosen to some degree, and because of this it is inalienable. There are, as Oksala observes, a 'variety of moral, political, and economic reasons' why 'the labor required for human reproduction cannot be completely commodified and brought into the sphere of market transactions' $(2016,299)$. This is not to deny the many 
cultural variations in how love is practiced nor is it to deny that the choice to love is culturally framed and context-specific, and that it can be reneged upon or not chosen in the first instance. But because love is generated in intentions and feelings for others, it cannot be bought and sold, in part because these feelings are not tied to a fixed-term contract. Love is defined through specific personal relationships and non-transferable; it is given in the contexts of pre-established relationships with a unique history and assumed but indefinite future which involves continuity and attachment (Barnes 2005, 8-9).

Moreover, the rationality of love labor is different from, and to some degree contradicts, scientific and bureaucratic rationality (Wærness 1984): there is no hierarchy or career structure to relations of love laboring. As the goal is the development of the relationship itself, the creating and recreating of rewarding, nurturing relationships with others, there is no identifiable beginning, middle, and end. One cannot pay someone to love someone else on your behalf, as to do so is remove the love dimension of the relationship. Put simply, one cannot pay someone to visit one's mother in hospital and claim that the visit is from oneself.

What also contributes to love's inalienability is that it is cannot be packaged and delivered in a neat pre-planned way. Love has a different 'temporal logic' to the 'profit-oriented rationality of the market economy' (Bryson 2013, 119). It takes time and presence on the part of the self, and one cannot segment it and assign it in bits and pieces to others. It has no clear boundaries and therefore cannot be done in the "measurable" time that commodification requires (Folbre $2004 ; 2012$ ). 'Lean and mean loving' would be a contradiction in terms, as a lean and mean relationship could not be a loving one. The illusion of reducing time for loving, by 
having 'quality time' with those one loves, is that it ignores the need for ordinary time and presence. Preliminary time in the (positive) presence of the other allows for the necessary trust and understanding to develop to have 'quality time'. If we try to "McDonaldize" caring what we will get is not care or love but "pre-packaged units of supervision": feeding or attending without intimacy or personal interest in the welfare of others (Badgett and Folbre 1999, 318). This inattentive caring may not only happen in professional care situations but within families as well, if love time is forcibly condensed to those times when one is likely to be preoccupied and tired, and only capable of 'loving in a hurry' - loving only with bits of left-over energy and time.

In suggesting that inalienability and non-commodifiability are defining features of love laboring, we are not saying that certain dimensions of secondary and tertiary care relations may not also be non-substitutable. The support provided by a good colleague at work or the commitment provided by an advocate for social justice in a given social movement is not replaceable in a direct sense. However, as the context and purposes of secondary and tertiary care relations are beyond the relationship itself, there are possibilities for substitution that do not apply in a primary love relationship.

The non-substitutability of love has significant gendered political implications. Women are the world's primary carers, not only in doing love laboring but also in doing secondary care laboring, which has greatly constrained their activism for love and care in the public realm. There are very real every-day conflicts between 'various forms of personal and political love relations' (Ferguson 2014, 260). Put simply, the loved one who needs 24 -hour-care cannot be left unattended while one attends conferences, marches, meetings or mobilizing events. Love 
and care cannot and will not become political issues until those who do the non-substitutable love laboring (most of whom are women) are at the political negotiating table. If we are to create the kind of caring democratic and feminist-inspired politics for which many feminists have called, the political table needs to be moved homewards, in the sense of taking the political agenda from the world of loving and caring rather than market capitalism. (Held, 2006; Tronto 2013; Ferguson 2014).

\section{Love as a Political and Social Justice Matter}

Love is a political matter because it is vital to creating caring infrastructures for democratic thinking and practice. It is love labor that produces the nurturing capital that enables people to flourish; it produces externalities, enabling and resourcing people, and giving meaning, warmth and joy to life outside of the love relationship itself (Lynch and Lyons 2009). Loves also matters politically for the enhancement of both democratic participation and sharing. The emotional ties and bonds that are part of loving and being loved encourage people to act as moral agents, and while they are partial, they promote relational responsibility to others (Tronto 2012). Thus, contrary to Hardt and Negri $(2009,182)$, while we recognize the partisan problematics of family love, the family is not necessarily a form of 'identitarian' 'corrupt love' as they suggest. It can be so, but the family, in its different manifestations, also provides a spatial and emotional site where mutualized other-centeredness can be lived and learned, and where the commitment and security of primary care can be sustained. It is a space where we learn to live 'other-wise'. 
Without learning and doing other-centeredness, it would be hard to create and maintain the most elementary forms of civic and political solidarity:

...public culture needs to be nourished and sustained by something that lies deep in the human heart and taps into its most powerful sentiments, including both passion and humor. Without these, public culture remains wafer thin and passionless, without the ability to motivate people to make any sacrifice of their personal self-interest for the sake of the common good (Nussbaum 2013, 43).

In effect, without the security of being loved and cared for, it is difficult to develop the capacity to go beyond the preoccupation of one's own personal security and well being, to go beyond a politics that is not entirely governed by self-interest. And 'without a more public conception of care it is impossible to maintain democratic society' (Tronto 2013, 18).

Love is also a political matter because the laws, economies and institutions created by the state have profound implications for who is loved and how they are loved. When states fail to provide supports for carers or for those in need of care, it undermines love by limiting the resources available to do it. When wages are so low that people need two or more jobs to survive they have little time for loving and caring in their intimate lives. When people are forced to migrate for economic or political reasons, their care worlds are often torn apart; those whom they love are often are left without care, while the migrant worker (especially if lowly paid) is frequently deprived of the affiliation and company of those they love. The preoccupation of contemporary capitalism with the production of more and more goods and services, and the incessant promotion of desire for more goods (Akerlof and Shiller 2015), has meant that 
working (and borrowing) to buy, and living to consume have become the raison d'être of existence in many Western countries (Crary 2013). Moreover, and for a variety of different and unrelated reasons, more and more women undertake both paid work and unpaid caring. In this 'second shift' framework women themselves, and those for whom they care, are squeezed between deadlines and timelines, none of which are determined by love and care needs (Hochschild, 1997). When they are middle class and career-trained, women often follow the male trajectory of long hours and assume a career-led life maintaining the image, and often the forced practice, of a relatively care-free life, even though they remain care's foot soldiers while men are care commanders (ibid, Lynch, Lyons and Cantillon, 2009b; Lynch, Grummell and Devine 2012). The process of consumption-led living in an already gendered capitalist economy presents a love labor and care challenge. Love and care deficits are increasingly addressed by hiring migrant women workers from poorer countries and regions of the world to do low-paid family and non-family care work in a new globalized coloniality that is as deeply racialized as it is feminized (Gutierrez-Rodriguez 2014). The care economy increasingly works on the assumption that women from the global south can leave their own children to earn a living caring and loving others with all the attendant love contradictions that operate both for themselves, those for whom they care, and their children or other dependents (Parreñas 2001; Hochschild 2009). The rise of neoliberal capitalism, and its focus on curbing public expenditure and cutting public services in particular, has exacerbated this trend and led to a growing decline in public care supports for children and vulnerable adults, even in previously strong welfare states (Karamessini and Rubery 2013). As consumption reigns, and as it takes more time and money to buy what one does (or does not) need, time for love labor is treated as a 
subsidiary activity that can be 'fitted in' after real work, and/or off-loaded (along with the dirty domestic work of caring) to low-paid care workers, be they migrants, local nannies or grannies (Hochschild 2009; Federici 2012).

If we want to create a better world, morally, politically and humanly, love needs to become a primary normative directive for the global order. We need to create societies where employment-related, political and cultural institutions recognize the importance of nurturing through love labor and allow people the time, space and energy they need to do love work in a way that is resourced, respectful and power-enhancing. Giving that loving space room to flourish will create a better example for children when they become adults to insist on a political economy that prioritizes love in time, space and resourcing.

The current organization of love and care means that women who are carers cannot have participatory parity within cultural, economic and political institutions, especially if they are on low incomes. As non-substitutable love workers without money, they have neither the time, space nor resources to engage in the political framing of issues, even issues that are central to their own existence (Crean 2016).

Thus, love is a social justice matter because the moral imperative on women to be primary carers ( $O^{\prime}$ Brien, 2007) disables them in public life when their love labor is not recognized as work and they literally have no time off to be political. It is also a social justice issue in the distributive justice sense, as love labor has both benefits and burdens that need to be shared on equal terms between women and men, and across classes and ethnic and racial groups. If 
those who are primary carers are to be enabled to contribute to society outside of their love and care working, love work has to be more equally distributed.

Love is also a social justice issue since being deprived of love is a serious human deprivation and injustice. Most people cannot thrive without love. Love and care are both a prerequisite for human development (Engster 2005) while solidarity is vital for good health and wellbeing (Wilkinson and Pickett 2009). Relations of solidarity, care, and love help to establish a basic sense of importance, value, and belonging, a sense of being appreciated, wanted and cared about. To deprive or deny someone the experience of love is to deprive them of one of the great "goods" of human existence (Nussbaum 2001).

\section{Love and Affective Politics}

The nurturing involved in producing people as mentally, socially and emotionally capable human beings constitutes a discrete system of affective relations, of which love is a core part. Given the centrality of affective relations to human survival, development and fulfilment, achieving equality in affective relations is vital for guaranteeing parity of participation in society. We believe that if social justice to be achieved, at local or global levels, it needs to be governed by four principles of justice rather than just the three proposed by Fraser (2008, 2010). While equality of re/distribution, respect/recognition and representation are vital to address economic, cultural and political injustices, there is also a need for relational justice so that affective inequalities are addressed. The reason the latter is so important is because 
affective inequalities are the generative site of injustice for many women throughout the world. The affective domain is also a site of injustice for those who are without a voice in the recognition, re/distributive and representational spheres of politics (which includes women who have no time or space to be political due the inalienable nature of their love work), children, those who lack cognitive capacity to articulate their political goals, and those who are institutionalized in places such as prisons where their call for love is silenced.

Affective relations also matter in terms of social justice because the worlds of love, care and solidarity are not isolated and autonomous spheres. They are deeply interwoven with each other and with economic, political, and cultural relations, and inequalities in the latter can undermine the capacities and resources to do love, care and solidarity work. Those who are poor and lack basic goods for survival often have little time for caring and love laboring in a manner that is emotionally and personally enriching (Crean 2016); those who are powerless (including people in prisons and those involuntarily incarcerated in other institutions such as the vulnerable elderly, the mentally ill and intellectually disabled ) are often seriously deprived of love and care, while those who are marginalized by their cultural positioning, including their sexuality, are, in many countries, deprived of intimate love and care because they are gay, lesbian or transgendered.

Like Ferguson (2014: 250-51, 256-7), we believe that love is sought because it meets fundamental human needs for care and affection; it is valued 'as something intrinsically good'. It 'energizes' and motivates people to act other-wise rather than self-wise, both in intimate relations but also at a wider group and political level. Love is endemic to our relationality and 
has liberatory potential because it '... is active, dynamic, determined and generates the motive and desire for justice' (Hill Collins 1990, 197). It 'has the power to transform us, giving us the strength to oppose domination' (hooks 2000,104 ). It is a positive force, a potentially powerful political force grounded in action, not an abstract sentiment. Love 'is not, as it is often characterized, spontaneous or passive. It does not simply happen to us, as if it were an event that mystically arrives from elsewhere. Instead it is an action, a biopolitical event, planned and realized in common' (Hardt and Negri 2009, 180). Because love is produced through the everyday nurturing involved in love labouring, it needs to be recognised, supported and shared. For this to happen the politics of love need to be mobilized in line with the core principles of feminist politics, many of which are still in the making (Ferguson 2014). We obviously recognize that societies cannot make anyone love anyone else, and to this extent the right to have loving, caring and solidarity relations is not directly enforceable. Even in the prototypical relationship in the primary circle, parents can be legally required to care for their children, but they cannot be forced to care about them. But societies can work to establish the conditions in which these relationships can thrive. In practical political terms this means that recognition of the importance of love and love labor needs to guide political decisions. In practical policy terms it would include at a minimum, maternity, paternity and parental leave that recognizes the nurturing needs of children and the emotional needs of parents; it would involve the provision of accessible, affordable public child care and elder/vulnerable adult-care supports for carers. It would also involve changing the 24/7 work culture that has become synonymous with many career-led white collar jobs; shortening the working day so everyone has quality time to give love and to receive love; setting wages at 
levels that were sustainable for a dignified, economically secure life; taxing excessive wealth globally and limiting income differentials between top and bottom earners. Mobilizing the revolutionary potential of love would also mean making education about love, care and solidarity central to all forms of education. Such education would raise the principle of othercenteredness to a new standing and demonstrate that human motivations are not solely driven by the ethics of competition and self-interest. Restraining the principle of rational economic interest and the politics of fear, both of which are central to contemporary capitalism, could, over time, create a political discourse that would enable people to think "other-wise" as well as "self-wise." A just economic and social policy would focus on the care-of-the-other in the context of caring of the self, thus breaking our present binary of egoism vs. altruism.

We believe that the potential for new modes of political engagement rests in affective relations and that equalizing the affective relations of love is as central to the politics of justice as Fraser's relations of redistribution, recognition and representation.

$<1>$ Late Fragment, Raymond Carver (1988).

$<2>$ We regard love as socially necessary work, vital to producing people in their humanness. It is not materially productive work in the classical economic (and Marxist) sense that it is exchangeable on the market nor is its primary purpose self-realization in the Hegelian sense. For further discussion see Lynch 2007.

<3> Among the political egalitarian theorists that exemplified this tradition are John Rawls, Charles Taylor and G.A. Cohen.

$<4>$ There can be an intense sense of belongingness and trust in primary care relations when they are positive, and of isolation, distrust, and pain when they are neglectful, exploitative, or abusive (See Gürtler 2005) . 
$<5>$ Heterosexual, lesbian, homosexual and transgender relations between couples are also potentially primary sites of intimacy. However, "The way heterosexual relations are institutionalized in contemporary society means that love's two elements - care and ecstasy - find themselves in continuous opposition ...." in a way that that is highly disadvantageous to women who are " 'forced' to commit themselves to loving care - so that men can be able to live/experience ecstasy" (Jonasdottir 1994: 102)

$<6>$ Such as those agreed collectively at national levels, e.g. through welfare state taxation, or at international levels through UN Conventions giving rights to people with disabilities.

\section{References}

Ahmed, Sara. 2004. Affective Economies. Social Text. 79 (22) 2: 117-139.

Akerlof, George and Shiller, Robert. 2015. Phishing for Phools: The economics of manipulation and deception. Princeton: Princeton University Press.

Badgett, M. V. Lee and Nancy Folbre. 1999. Assigning care: Gender Norms and Economic Outcomes. International Labour Review. 138 (3): 311-326.

Baker, John, Kathleen Lynch, Sara Cantillon and Walsh, Judy. 2004. Equality: from theory to action. Basingstoke: Palgrave Macmillan.

Barnes, Marian. 2005. Caring and Social Justice. London: Palgrave Macmillan. 
Benhabib, Seyla. 1992. Situating the Self: Gender, community, and postmodernism in contemporary ethics. New York: Routledge.

Bryson, Valerie. 2013. Time to Love. In Ferguson, Ann and Anna G. Jónasdóttir (Eds.) Love: A question for in the twenty-first century. New York: Routledge: 113-126.

Bubeck, Diemut Elisabet. 1995. Care, Justice and Gender. Oxford: Oxford University Press.

Crary, Jonathan. 2013. 24/7 Late Capitalism and the Ends of Sleep. New York; Verso.

Crean, Margaret (2016) Care Consciousness: Classed care and affective equality. Unpublished PhD School of Social Justice, Dublin: University College Dublin.

Damasio, Antonio. 2006. Descartes' Error: Emotion, reason and the human brian. London: Vintage Books.

Delphy, Christine and Leonard, Madeleine. 1992. Familiar Exploitation: A New Analysis of Marriage in Contemporary Western Societies. Cambridge: Polity Press.

Engster, Daniel. 2005. Rethinking care theory: The practice of caring and the obligation to care. Hypatia: A Journal of Feminist Philosophy. 20 (3): 50-74

England, Paula (2005). Emerging Theories of Care. Annual Review of Sociology 31:381-99

Federici, Sylvia. 2012. Revolution at Point Zero: Housework, reproduction and feminist struggle. PM Press/Common Notions/Autonomedia. 
Ferguson, Ann. 1989. Blood at the Root; Motherhood, sexuality and male domination. London: Pandora/Unwin \& Hyman.

Ferguson, Ann. 2014. Feminist Love Politics: Romance, Care, and Solidarity. In Ferguson, Ann and Anna G. Jónasdóttir (Eds.) Love: A question for in the twenty-first century. New York: Routledge: 250-264.

Fineman, Martha 2004. The Autonomy Myth: A theory of dependency. New York: The Free Press.

Folbre, Nancy. 1994. Who Pays for the Kids? Gender and the structures of constraint. London: Routledge.

Folbre, Nancy 2004. A Theory of the Misallocation of Time. In Family Time: The social organization of care. Eds. Nancy Folbre and Michael Bittman. London: Routledge.

Folbre, Nancy (ed.) 2012. For Love and Money: Care provision in the United States. New York: Russell Sage Foundation

Fraser, Nancy. 1997. After the Family Wage: A post-industrial thought experiment. In Justice Interruptus: Critical reflections on the 'postsocialist' condition. (ed.) Nancy Fraser. London: Routledge

Fraser, Nancy. 2005. Reframing Justice in a Globalizing World. New Left Review 36: 69-88.

Fraser, Nancy. 2008. Scales of Justice: Reimagining political space in a globalizing world. Cambridge: Polity Press. 
Fraser, Nancy. 2010_. Injustice at Intersecting Scales: On 'Social Exclusion' and the 'Global Poor'. European Journal of Social Theory 13(3): 363-371.

Gilligan, Carol. In a Different Voice. Cambridge MA: Harvard University Press. 1982.

Gilligan, Carol. 1995. Hearing the difference: Theorizing connection. Hypatia: A Journal of Feminist Philosophy. 10 (2): 120-127.

Gürtler, Sabine. 2005. The ethical dimension of work: A feminist perspective. Translated by Andrew Smith. Hypatia: A Journal of Feminist Philosophy 20 (2): 119-134.

Gutierrez-Rodriguez, Encarnacion. 2014. Domestic work-affective labor: On feminization and the coloniality of labor. Women's Studies International Forum 46: 45-53.

Habermas, Jurgen. 1981. The Theory of Communicative Action. Boston, Mass.: Beacon Press.

Hardt, Michael and Negri, Antonio. 2009. Commonwealth. Cambridge MA: Harvard University Press.

Held, Virginia. 2006. The Ethic s of Care: Personal, political and global. Oxford: Oxford University Press.

Hill Collins, Patricia. 1990 Black Feminist Thought: Knowledge, consciousness, and the politics of empowerment. Boston. Unwin Hyman.

Hochschild, Arlie Russell. 1979. The Managed Heart: Commercialization of human feeling. Berkeley: University of California Press 
Hochschild, Arlie Russell. 1997. The Time Bind: When work becomes home and home becomes work. New York: Metropolitan Books.

Hochschild, Arlie Russell. 2009. Love and Gold. S\&F Online 8 (1): 1-

6 http://sfonline.barnard.edu/work/hochschild 01.htm accessed August 13th 2015

Honneth, Axel. 2003. Redistribution as Recognition: A Response to Nancy Fraser. In Nancy Fraser and Axel Honneth Redistribution or Recognition? A political-philosophical exchange trans. by Joel Golb, James Ingram, and Christiane Wilke. London: Verso: 110-197.

hooks, bell. 2000. All About Love. New York: William Morrow \& Co.

Jónasdóttir, Anna G. 1994. Why Women are Oppressed. Philadelphia: Temple University Press. Karamessini, Maria and Jill Rubery. 2013. Women and Austerity: The economic crisis and the future for gender equality. London: Routledge.

Kittay, Eva Feder. 1999. Love's Labor. New York: Routledge.

Lakoff, George. 2008. The Political Mind: Why you can't understand $21^{\text {st }}$-century politics with an $18^{\text {th }}$-century brain. New York: Penguin.

Lanoix, Monique. 2013. Labor as embodied practice: The lessons of care work. Hypatia 28 (1): 86-100.

Lynch, Kathleen. 2007. Love labour as a distinct and non-commodifiable form of care labour. Sociological Review 54 (3): 550-570. 
Lynch, Kathleen. 2014. Why love, care and solidarity are political matters: Affective equality and Fraser's model of social justice. In Love: A question for feminism in the twenty-first century, eds. Ann Ferguson and Anna Jónasdóttir. New York: Routledge: 173-189.

Lynch, Kathleen, John Baker and Maureen Lyons (Eds.) 2009. Affective Equality: Love, care and injustice. Basingstoke: Palgrave Macmillan.

Lynch, Kathleen and Maureen Lyons. 2009. Love Labour: Nurturing Rationalities and Relational Identities. In Affective equality: Love, care and injustice, eds. Kathleen Lynch, John Baker and Maureen Lyons. Basingstoke: Palgrave Macmillan: 54-77.

Lynch, Kathleen, Maureen Lyons and Sara Cantillon. 2009a. Love labouring: power and mutuality. In Affective equality: Love, care and injustice, eds. Kathleen Lynch, John Baker and Maureen Lyons. Basingstoke: Palgrave Macmillan: 114-131.

Lynch, Kathleen, Maureen Lyons and Sara Cantillon. 2009b. Time to care, care commanders and care foot soldiers. In Affective equality: Love, care and injustice, eds. Kathleen Lynch, John Baker and Maureen Lyons. Basingstoke: Palgrave Macmillan: 132-157.

Lynch, Kathleen, Bernie Grummell and Dympna Devine . 2012. New Managerialism: commercialization, carelessness and gender. Basingstoke: Palgrave Macmillan.

Matheis, Christian. 2014. On Various Notions of "Relations" in Enrique Dussel's Philosophy of Liberation. Hispanic/Latino Issues in Philosophy 13 (2) -15 
Mattingly, Cheryl. 2014. Love's imperfection - Moral becoming, friendship and family life. Suomen Anthropologies: Journal of the Finnish Anthropological Society 39 (1): 53-67

McKie, Linda, Susan Gregory and Sophia Bowlby. 2002. Shadow Times: The temporal and spatial frameworks and experiences of caring and working. Sociology 36 (4): 897-924.

Meagher, Gabrielle. 2002. Is it wrong to pay for housework? Hypatia 17(2): 52-66.

Mohanty, Chandra Talpade. 2003. Feminism without Borders: Decolonizing theory, practicing solidarity, Durham, NC: Duke University Press.

Nussbaum, Martha. 1995. Emotions and Women's Capabilities in Women, Culture and Development: A study of human capabilities. Martha Nussbaum and Jonathan Glover (eds.) Oxford: Oxford University Press: 360-395.

Nussbaum, Martha. 2001. Upheavals of Thought: The intelligence of emotions. Cambridge: Cambridge University Press.

Nussbaum, Martha. 2013. Political emotions: Why love matters for justice. Cambridge, MA: Harvard University Press.

O’Brien, Maeve. 2007. Mothers' Emotional Care Work in Education and its Moral Imperative. Gender and Education. 19 (2): 159-177.

Okin, Susan Moller. 1989. Justice, Gender, and the Family. New York: Basic Books. Oksala, Johanna 2016. Affective Labor and Feminist Politics. Signs 41 (2): 281-303. 
Parreñas, Rhacel Salazar. 2001. Servants of Globalization: Women, migration, and domestic work. Stanford, CA: Stanford University Press.

Qureshi, Hazel. 1990. A research note on the hierarchy of obligations among informal caregivers - a response to Finch and Mason. Ageing and Society 10: 455-458.

Ruddick, Sara. 1990. Maternal Thinking: Towards a politics of peace. London: Women's Press.

Scholz, Sally J. 2007. Political Solidarity and Violent Resistance. Journal of Social Philosophy (38) 1: $38-52$.

Sevenhuijsen, Selma. 1998. Citizenship and the Ethics of Care: Feminist considerations on justice, morality and politics. London: Routledge.

Strazdins, Lyndall, and Dorothy H. Broom. 2004. Acts of love (and work):gender imbalances in emotional work and women's psychological distress. Journal of Family Issues 25 (3):356-378.

Toye, Margaret. 2010. Towards a poethics of love. Feminist Theory. 11 (1): 39-55.

Traustadottir, Rannveig. 2000. Disability reform and women's caring work. In Care work: Gender, class and the welfare state, ed. Madonna Harrington Meyer. London: Routledge. Tronto, Joan. 1987. Beyond Gender Difference to a Theory of Care. Signs. 12 (4): 644-663.

Tronto, Joan. 1993. Moral Boundaries: A political argument for an ethic of care. New York: Routledge. 
Tronto, Joan. 2012. Partiality Based on Relational Responsibilities: Another Approach to Global Ethics. Ethics and Social Welfare. 6 (3): 303-316.

Tronto, Joan C. 2013. Caring Democracy: Markets, equality and justice. New York: New York University Press.

Wærness, Kari. 1984. The Rationality of Caring. Economic and Industrial Democracy 5 (2): 185211.

Wilkinson, Richard and Kate Pickett. 2009. The Spirit Level: Why more equal societies almost always do better. London: Allen Lane. 